Прегледни чланак

34(495.02)“03/14“"

doi:10.5937/zrpfns54-17584

Milan M. Macura, Ph.D. Student

University of Belgrade

Faculty of Law Belgrade

milan.macura992@gmail.com

\title{
BYZANTINE LAW AS A NURSERY GARDEN FOR LEGAL TRANSPLANTS WITH SPECIFIC REVIEW OF DUSAN'S CODE
}

\begin{abstract}
The term Byzantium or Byzantine Empire is used for a state creation that existed from the 4th to the 15th century, more precisely until 1453 and the fall of Constantinople due to the Ottoman conquests. Regardless of what historical discussions and opinions otherwise differ regarding the origin of Byzantium, in this scholarly work May $11^{\text {th }}, 330 \mathrm{AD}$, was taken as the beginning of the Byzantine Empire, the date when New Rome came into existence (Greek

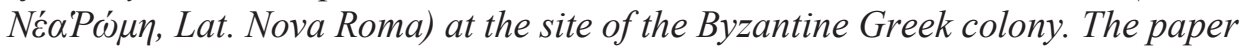
will analyze the influence of Byzantine law on the further development of the law in the world, as well as the temporal continuity and development of Byzantine law that relies on Roman law. In addition, through a comparison of the Byzantine Code Members and later Dusan's Code, the theory of legal transplants developed by Alan Watson will be analyzed.
\end{abstract}

Keywords: Byzantine law, legal transplants, development of law, Byzantine Empire, Roman law.

\section{INTRODUCTION}

The basis of Byzantine law lies in Roman and canon law, that is, the law of the Orthodox Church. This law, subject to the influence of other laws such as Roman and customary law, developed from 330 to 1453 AD. The biggest link through which Byzantine law exerted influence was the so-called Byzantine Commonwealth ${ }^{1}$ y which included the Serbian state as an Orthodox state. This is

\footnotetext{
${ }^{1}$ The term comes from Dimitri Obolensky and was created in 1971. The Byzantine Commonwealth-Eastern Europe 500-1453.
} 
supported by the geographical location of Byzantium, which was located on three continents (Europe, Asia, and Africa) in areas such as Balkan Peninsula, Asia Minor, Apennine Peninsula, Mediterranean sea, Iberia, Middle East, Crimea, Caucasus, and North Africa - areas that were then centers of cultural and social development. $^{2}$

The greatest influence on the preservation of the law was exercised by the emperors, who, through hard work, recognizing the necessity, codified existing law and modified it according to the needs of society. The first in Byzantium to work on this was Theodosius II (408-450 AD), who published Theodosius Codex in $438 \mathrm{AD}^{3}$ (lat. Codex Theodosianus). It is a code that preceded Justinian's codification and which laid the further ground for the development of the codifying activity of the Eastern Roman emperors. It covered the laws of the period of Constantine the Great (324 - 337 AD) (from the Edict of Milan in 313 AD) to the laws passed by Theodosius II. ${ }^{4}$

Then came the re-codification and legislative process that had Theodosius Code as the starting point, along with Gregorian and Hermogenian collections. Tribonian together with his fellow jurists produced a collection of valid imperial laws passed by Hadrian (117-1988 AD) and Justinian (527-565 AD), along with the laws of other emperors, and this collection was issued in 529 AD. Five years after that, a supplementary collection was issued that was far more extensive. ${ }^{5}$

Later on, Justinian's Digests (Pandects) were drafted, the most comprehensive codification of Roman law by classical Roman jurists. Later Justinian Institutions are a textbook of law and serve as a kind of manual for the study of law. The last section of the Novels consists of the enacted regulations that were issued after codification.

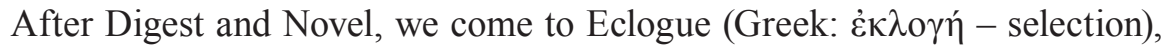
which was created in 726 AD. ${ }^{6}$ Eclogue reformed inheritance and criminal law and introduced some changes to Justinian's sentencing legislation. For example, death sentences were replaced with corporal punishments carried out by cutting nose or hands-off, blindness, haircuts, etc. The eclogue made great progress in the field of humanization of criminal law and contributed to the then direction of philanthropy. It improved the litigation process because it was drafted as a certain

\footnotetext{
${ }^{2}$ Georgije Ostrogorski, History of Byzantium, Prosveta, Belgrade 1969, 4.

${ }^{4}$ John Murray, Codex Theodosianus, A Dictionary of Greek and Roman Antiquities, London $1875,43$.

${ }^{5}$ Johannes Coder, Byzantine World, Utopia, Belgrade 2011. 75,

${ }^{6}$ Although the reign of Emperor Leo III lasted from 726 until 741, it is believed that the Eclogue was not enacted in 741, as some authors claim; the reason for this is the iconoclasm movement that was active in Byzantium in 741, which includes a religious movement that fought against frescoes, icons, statues and other visual representations that exist in their religion, and Eclogue does not even contain the traces of this movement.
} 
court manual unlike Digests at the time, which, due to their size and character, were incomprehensible. ${ }^{7}$ Eclogue has also made significant progress in the field of children's and women's rights. In addition, Eclogue was partly concerned with judicial organizational law as it determined judges' salaries, starting with the Quaestors ${ }^{8}$. It was a ceratin step in reducing the corruption that was tearing up the Byzantine Empire at the time.

After the death of Leo III (717-741 AD), Vasily I (867-886 AD) came to power in Byzantium, to whom the enactment of Procheiron was associated (Greek

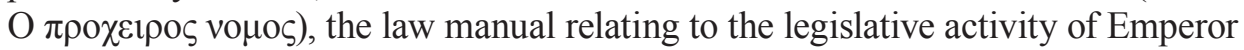
Vasily of Macedonia and his sons Constantine and Leo. In that time, Procheiron was the most comprehensive codification since it contained all the parts of the Institutions, Digest, Novel and Code that were force and in the true sense of the word was a legal transplant since it was later incorporated into the Nomocanon of Saint Sava (Krmcija) in the part with ecclesiastical criminal law and Dusan's Code, which were the most important legal acts in medieval Serbia. At that time, Procheiron was known in Serbia as City Law. Procheiron regulated public and civil law. It is assumed to have been issued between 870 and $879 \mathrm{AD}$. The fact that it remained in force until the fall of Constantinople makes it one of the longest standing legal acts in Byzantium, which is impressive.

Legal Act issued later - Epagoge introduces the obligation of the emperor to take care of the material treasure of the citizens, while the spiritual treasure is taken care of by the patriarch. Also, this is one of the few par excellence examples of legal transplants when we consider that later legal acts adopted in Europe, and especially Serbia, from Krmcija to Dusan's Code, implied this obligation on the heads of the church and emperor or ruler. The epanagoge was enacted after 879 $\mathrm{AD}$ and represents the codifying endeavor of the three emperors (Alexander, Leo, and Vasily), and regulates mainly marital law. ${ }^{9}$

Following the Epanagoge, the following legal acts that were issued were Vasilike the Lion VI the Wise (866-912 AD), who in the whole continued the work that began with Vasily. The enactment of Vasilika or the Imperial Laws is a very comprehensive and thorough codifying activity, as is evidenced by sixty books and six volumes, which is the largest codification collection of Byzantium in the Middle Ages. Vasilikas deal with both canonical and civil and public law. ${ }^{10}$ The fact that they are comprehensive codification is evidenced by the fact that Vasilika

${ }^{7}$ G. Ostrogorski, 166-177.

${ }^{8}$ Quaestor, a Roman official in charge of public finances and overseeing the Treasury. In war conquests, they were accompanied by a consul, and they were in charge of paying the army and distributing the loot of war. In addition to these quaestoes classici, there were quaestores in charge of criminal offenses (quaestors parricidii).

${ }^{9}$ J. Coder, 79.

${ }^{10}$ Charles Diehl, History of the Byzantine Empire, Edition, Belgrade 2010, 58. 
draws its material from both Digest and the Code, not so much from the Justinian Institutions as from the Justinian Novels as well as Tiberius Novels. It also includes material from Justin II Novels (565-574 AD). One of the crucial reasons for Vasilika's prevalence is that they were written in Greek and thus found their way through an Orthodox clergy that spoke mostly Greek until Serbian law and later to European law. The fact that they were almost completely suppressed by the Justinian Code and became the very foundation of the Byzantine Empire's laws with later Novels and Orders (113 of them) suffices to say that this was a very significant path.

\section{BREAKTHROUGH OF BYZANTIAN LAW IN SERBIAN LAW VIA LEGAL TRANSPLANTS}

One of the easiest ways to transmit legal standards and legal norms is through the same language or religion. ${ }^{11}$ In this way, the path to Serbian law was facilitated because the baptism of Serbs at that time, which took place in the ninth century, played a large role in the further future of Serbian law. Beginning with the code of Theodosius and to Vasilika, in Serbian law there remained an indelible trace of the Byzantine Empire that still exists today. Legal transplants and theory believe that the development of law throughout history has been facilitated by the intermingling of cultures that have been systematically occurring over the years, and that law has also changed over time. ${ }^{12}$ The theory brought to us by Alan Watson, a leading authority in the field of comparative law, can perfectly describe how people adopt certain legal rules or how customs settle in one's law and make certain categorizations.

The first group that as such participates in cultural unification is one that inhabits a particular area in which no nation or civilization is culturally or legally similar to them, and in that case, they exercise their right. The second grouping is one that inhabits a particular area where there is a nation or civilization that is culturally and legally similar to theirs. The third group is the one who inhabits a certain area and, in that case, accepts a large part of a particular system and assimilates into the cultural and legal type of civilization and people they found..$^{13}$

One reason for the successful transfer of the Byzantine right to Serbian could be that each of the Serbian rulers tended to look upon Byzantium. Dusan Silni $(1331$ - 1355) succeeded when he was granted the imperial title because that title was unique in the Orthodox world and according to the hierarchy of states, there could be only one empire, namely Byzantium. The reason and explanation for this

${ }^{11}$ Alan Watson, Legal Transplants: An Approach to Comparative Law, Official Gazette, Belgrade, 2008, 36.

${ }^{12}$ Sima Avramovic, General Legal History - Old and Middle Ages, Belgrade 2000, 21.

${ }^{13}$ A. Watson, 58. 
can be seen in Dusan's Code, which in its first article brings the purification of Christianity as its goal. When we talk about connection, we cannot omit the connection between Byzantine collections and Syntagma by Matthias Vlastar, who in a certain way empowered and paved the way of Byzantine law in Dusan's Code. Vasilika is the legal act with the most similarities, about 60 articles of Dusan's Code have been taken from Vasilika.

The first chapter of Vasilika's first book bears the title De summa tirnitete et de fide catholica, et ut nemo de ea publica contendere audeat. ${ }^{14}$

There is a similarity to the introductory part, in front of the A-composition of Syntagma by Matthias Vlastar, entitled „O vhrh pravoslavnoi““.15

Article 2 and Article 3 of Dusan's Code

About marriage:

Gentry -and other people not to marry without the blessing of their Bishop, or to be blessed by those appointed by the Bishops by choosing them as priests. ${ }^{16}$

About wedding celebration:

About wedding celebration: No wedding can be done without a wedding celebration, and if done without a blessing and asking the church, they will be distinguished..$^{17}$

The reason why the two provisions were found in Dusan's Code is not known, but it is assumed that the reason is that they are not in the Vlastar's Syntagma. Also, the source of these two provisions can be found in the imperial orders of the Byzantine emperors. They are not found in any codex, which tells us that there was, nevertheless, a legal tradition that contributed to the preservation of this rule as custom, until Emperor Lav the Wise recorded it in his Novel in $893 \mathrm{AD}^{18}$ and thus creates a monopoly in the field of marriage among the citizens of the Byzantine Empire. However, despite this provision, many marriages were still contracted out of all the rules of custom and law, which created a disturbance in legal affairs. Later, slaves also had an obligation to marry, and they were obliged to do so in the church. ${ }^{19}$ The ruler who brought this Novel was Emperor Alexei Komnin $\left(1081\right.$ - 1118), who did so in $1095 .{ }^{20}$ Later, this provision came into Serbian legislation when Emperor Andronicus II Paleologus and Patriarch Athanasius brought

${ }^{14}$ Stojan Novakovic, Syntagma of Matthias Vlastar, Belgrade 1907, 48.

${ }^{15}$ Nikola Radojcic, Code of the Emperor Stefan Dusan 1349 and 1354, Belgrade 1960, 144.

${ }^{16}$ Djurica Krstic, Dusan's Code: Bistrica transcript, Belgrade 1994.

${ }^{17}$ Dj. Krstic, Dusan's Code: Bistrica transcript, Belgrade 1994.

${ }^{18}$ Aleksandar Vasiljevich Solovyev, Code of the Emperor Stefan Dusan, emperor of Serbs and Greeks, 103; C. Mitrovic, Ecclesiastical law, Belgrade 1929, 143.

${ }^{19}$ St. Novakovic, Code, 152.

${ }^{20}$ C. E. Zachariae v. Lingenthal, Collectio Novelarum = Jus Graeco-Romanum, III, Lipsiae 1873, IV, n. 35 . 
a novel that specified that each marriage had to be made in the presence of a priest, that is, as they stated, with the knowledge of the priest. ${ }^{21}$ In this way, the "transplant" of the legal transplant into the Serbian codification occurred, and no mistake was made as it had happened to the Byzantine emperors, which is that this provision could not be found in large imperial collections. Autonomy has been given to the ecclesiastical judiciary, which can be seen from Article 12 of Dusan's Code. The Church had the powered to judge: 1) in matters within its jurisdiction such as marriage and inheritance litigation, all clergy in any field, as well as criminal offenses against the church and to prevent heresy; 2) the Church stock members for all acts, both civil and criminal; 3) to all persons, especially peasants, on church property. ${ }^{22}$

We can find these provisions in two places, and this tells us that this is a legal transplant that marked the church judiciary in Serbia through the Middle

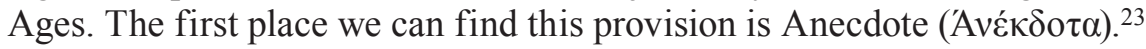

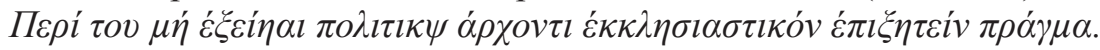

Civili magistrtui ne liceat in rem ecclesiasticam inquirere. ${ }^{24}$

In addition, we can also find this provision in the Vlastar's Syntagma, in chapter nine of paragraph $\mathrm{D}$, where the legislator also introduced a provision punishing the saint, who judged instead of the church in spiritual cases, with 300 perpers..$^{25}$

\section{LEGAL TRANSPLANTS IN THE FIELD OF CRIMINAL LAW IN DUSAN'S CODE}

One of the first offenses referred to in Dusan's Code is criminal offense from Article 19 - the overthrow of races.

On the overthrow of races:

And a nun who overthrows races, to be held in prison until he returns to obedience, and to be punished.

The very title of the Article indicates Byzantine influence ${ }^{26}$. In addition to the etymological correspondence with Byzantine law, this norm can also be found in the CXXIII Novel, which is part of Vasilika and as such has been transplanted into Dusan's Code. ${ }^{27}$

${ }^{21}$ C. E. Zachariae v. Lingenthal, Collectio, V, n. 26, c. 11; A. V. Solovjev, Legislation, 103.

22 A. V. Solovyev, Code of the Emperor Stefan Dusan 1349 and 1354, Sources of Serbian Law 6, Belgrade 1980, 181.

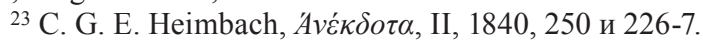

${ }^{24}$ Nikola Selakovic, Dusan's Code and legal transplants, Belgrade 2007, 28.

${ }^{25}$ St. Novakovic, Syntagmat, Chapter 9, paragraph D, 226.

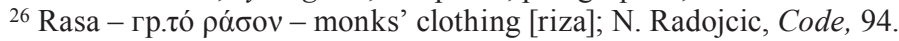

${ }^{27}$ Basil. Lib. IV, Tit. I, XIV = Nov. CXXIII, sar. XLII. 
Also, there is a certain immunity of ecclesiastical persons, which is expressed in Article 30 of Dusan's Code and which reads as follows:

And henceforth, that no authority shall rip the beard/hair of a monk or a man of the church, and whoever bypasses this for the life and after the death of my kingdom, shall not be blessed; if anyone is to blame for anything, one should make him go to court and press charge, if one rips the beard/hair without a court, or if one hits another, one has to pay sevenfold. ${ }^{28}$

In addition to the particular immunity given to ecclesiastical persons in this Article, this is not the only place in Dusan's Code where we can find this attitude towards ecclesiastical persons. Also, self-sitting is a punishment that we find in the following Articles: 93, 102, 143, 187, 193 and 200. Self-sitting is an institute developed by the Byzantine jurists by interpreting Scripture, which implies that a person who has concealed an "offense", committed a "sin" or broke a custom, he should make up for it seven times. So once for the damage done and six more times. Most authors, as well as Solovyev, one of the leading legal historians, note that the punishment was not known to other Germanic or Slovenian peoples. ${ }^{29}$

The interpretation of Scripture that originated in Constantinople contains the view that it is commensurate to punish a guilty person and a convicted person

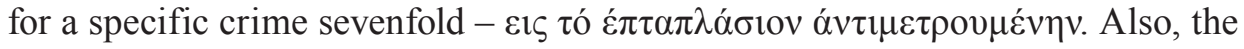
Novel of Emperor Manojlo Komnin $(1143$ - 1180) from 1165 prescribes in several Articles this system of punishment. ${ }^{30}$

Dusan's Code also prescribes the criminal offense of rape contained in Article 53. Rape offense existed in Serbian customary law before, but the sanction provided for in the Code for the commission of this crime, tells us that it is a sanction that with its intensity could be found in Byzantine law.

About violence:

If any landlord takes landlady by force, his hands and his nose should be cut off;

If sebar takes landlady by force, he shall be hung, if he takes his lady by force, his hands and his nose should be cut off. ${ }^{31}$

Prohiron (XXXIX, 66) prescribes, in one of the laws, as punishment for rape, cutting the nose off and confiscation of $1 / 3$ of property. ${ }^{32}$ The law as such has been transmitted to Syntagma and to its Serbian editorial board, which has been ab-

${ }^{28}$ A. V. Solovyev, Code, 171.

${ }^{29}$ A. V. Solovyev, Code of the Emperor Stefan Dusan 1349 and 1354, Sources of Serbian Law 6, Belgrade 1980, 195.

${ }^{30}$ Ibid, 196.

${ }^{31}$ Dj. Krstic, Dusan's Code: Bistrica transcript, Belgrade 1994.

${ }^{32}$ E. H. Freshfield, A manual of Eastern Roman law THE PROCHEIROS NOMOS, Cambridge MCMXXVIII, 156. 
breviated. In Dusan's Code, the penalties were considerably tightened, but at the same time, the legislature was able to adapt the provisions of the law to the class circumstances of the Serbo-Greek Empire. ${ }^{33}$ The penalties prescribed by the Code are similar to the Byzantine ones (penalties such as the cutting the hands- off); cutting the nose off was also present, but so was the death sentence, which was carried out by hanging, which was intended for the sebar who would rape the landlady. The penalty by hanging ( as one of the most shameful punishments by being executed publicly and as soon as possible and before the act of hanging the verdict was read in public as well as the reason for executing that sentence..$^{34}$

In addition to the above crimes, there are many examples where one can see the similarities of Byzantine law with Serbian, both through provisions regarding the prescribing of the objective conditions of crime incrimination and prescribing sanctions that were characteristic of Byzantine law. In some places, the legislature, in Dusan's Code, merged the offenses into one Article if those offenses were prescribed as two separate offenses. An example of this is a crime related to the obscenity of a woman and to the adultery of a woman who was placed in Article $54^{35}$ Dusan's Code and thus received a more general tone with harsher sanctions. The nuance that gives it a more general tone compared to Prohiron is that it omits the distinction made by Prohiron. Instead of the word slave, the word man is used, under which any subject who serves his master can be placed, which can be a meropach $^{36}$, otrok ${ }^{37}$ and servant. ${ }^{38}$

Dusan's Code also introduces the punishment of perdition, which meant that the beard and hair would be dirty, leaving a trace that would stay for some time. In Byzantium, a pandan to that punishment would be the punishment of a haircut intended to dishonor a convicted person and to deter those who intend to commit a crime. Regardless of the specific similarity in the execution of the sentence, the

${ }^{33}$ A. V. Solovyev, Code of the Emperor Stefan Dusan 1349 and 1354, Sources of Serbian Law 6, Belgrade 1980, 218

34 A. V. Solovyev, Code of the Emperor Stefan Dusan, emperor of Serbs and Greeks, 103; C. Mitrovic, Ecclesiastical law, Belgrade 1929, 182.

${ }^{35}$ Despite being placed in the same Article, we have two separate criminal offenses.

${ }^{36}$ Dusan's Code also discusses the problem of fugitive merophas in several Articles. First, in Article 22, we read: And the lords of men, who sit in the village and on the catuns, to visit the village with their lord. For more see: Srdjan Sarkic, "The Legal Position of Meropachs in Medieval Serbia", Proceedings, Faculty of Law, Novi Sad 2/2010, 26.

37 The lowest rank on the social ladder of medieval Serbia was the so-called otroci (singular $=$ otrok). The legal position of an otrok in medieval Serbia was similar to that of a slave, but as otrok also enjoyed some personal rights, many questions regarding their legal status remain debatable. For more on this, see: S. Sarkic, "The Legal Position of Vlach and Otrok in Medieval Serbia”, Proceedings, Faculty of Law, Novi Sad 3/2010. 44.

${ }^{38}$ E. H. Freshfield, A manual of Eastern Roman law THE PROCHEIROS NOMOS, Cambridge MCMXXVIII, 156. 
implication of the sentence of imprisonment came from the East. The reason for this is that in the East and the Eastern civilizations, beard and hair were considered a status symbol and also symbolized dignity.

The haircut to "bare skin" was reserved for slaves so that was a humiliating sentence appropriate to the offender's social status. ${ }^{39}$

Of the other penalties that were taken from Byzantine law and included in Dusan's Code, we have enmity that was paid either individually or the whole village paid enmity. To some extent, the collective responsibility institute applies here. An example of this can be found in Article 20 of Dusan's Code, which reads as follows:

About the sorcerers, who burn the bodies of the dead: And the people who take things from the graves by using the spells and burning the bodies, the village that does it, is to pay the devil, and if a priest comes to it, he will no longer be the priest. ${ }^{40}$

One of the most interesting articles pointing to the breakthrough of Byzantine law (a provision taken from the Greek Nomocanon by the Great Belt, ed. Translated by A. Pavlova, page 145) also mentions werewolves and the punishment imposed on anyone who violates this order, namely is twenty-one years of epithymia. The act of execution is the removal of the body from the grave and the subsequent burning of the body. The punishment for this offense, if committed by more than one peasant, is a fine of 500 perpers. An interesting coincidence, which has not yet been explained, is that the same fine as when the murder was committed. A priest who would participate in the act itself, reading a thunderbolt and saying words that swear an evil spirit, would no longer be able to be a priest. ${ }^{41}$ Such provisions are not found in Syntagma of Matthias Vlastar, which contains a special head regulating the disrespect for graves and the deceased. Chapter $10 \mathrm{~T}$ of the composition and its final provisions concern the rules of contempt for the deceased and the graves. The legislature's reason for criminalizing this behavior in Dusan's Code is to eradicate another custom with a pagan background that was happening among Serbs.

${ }^{39}$ Some authors state that this punishment was not carried out in reality, only that it is the result of speculations of certain authors. However, we find a confirmation of the execution of this sentence in the 1161 Ipatiian yearbook. In addition, we find information about the execution and the threat that this sentence would be executed when the Serb authorities in Konavle threatened their peasants in 1349 that they would be punished in this way. The term used for this is comburere barbam et capud.

${ }^{40}$ Dj. Krstic, Dusan's Code: Bistrica transcript, Belgrade 1994.

${ }^{41}$ A. V. Solovjev, Code of the Emperor Stefan Dusan 1349 and 1354, Sources of Serbian Law 6, Belgrade 1980 


\section{CONCLUDING REMARKS}

An empire that has lasted for over a thousand years has enacted legal regulations that still to the present day is the image many lawyers look up to. Regardless of its rigidity and the severe repressive character it had in some areas, it paved the way for the progress of the law itself. Testimony from sources assures us that Dusan's legislative work was not confined to the national assemblies of 1349 in Skopje (brought 135 Articles) and 1354 in Ser (brought Articles 136-201), but that the emperor's intention was to, modeled after his idols, (the great Roman emperors of the legislature Justinian, Vasily I and Leo VI the Wise) revise all the previously enacted legal rules, secular and ecclesiastical, and to create a single legal system. ${ }^{42}$ The Articles given in Dusan's Code are one of many that see the transfer of rights and the incorporation of Byzantine law into the positive law of the Serbian state that existed during that period. These articles are representative because one can see the impact not only on one branch of law, but in all branches of law. The purpose of this analysis was to show, regardless of the generality or imprecision of the theory of legal transplants, that it is a theory that no lawyer can bypass and which still has a tremendous influence in the development of law in general.

The long period of the Byzantine Empire has left its mark. Even though it was created as a result of the fall of Constantinople in 1453, it has confirmed two theories that exist in the field of law today - the theory of legal pluralism and the theory of legal transplants. This paper aimed to analyze the theory of legal transplants in practice and to express the positive response of the author to that theory. The provisions of the Byzantine emperors, adapted both to the social status and the wider circumstances that existed during that period, found their place in Serbian Codes. Such an endeavor by the legislature must not be ignored.

\section{REFERENCES}

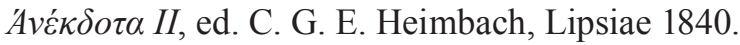

A. V. Solovyev, Selected Monuments of Serbian Law, Belgrade 1926.

A. Watson, Legal transplants, Belgrade 2000.

A. V. Solovyev, L'influence du droit Byzantin dans les pays ortodoxes, X Congresso Internazionale di Scienze Storiche - Roma, 4-11 Settembre 1955, Relazioni generali e supplementi VI, Firenze 1955

A. V. Solovyev, Code of the Emperor Stefan Dusan 1349 and 1354, Sources of Serbian Law 6, Belgrade 1980

Basilicorum libri LX - I, ed.C. G. E. Heimbah, Lipsiae 1833

${ }^{42}$ C. Sarkic, "The Idea of Rome in the Thought and Work of Emperor Dusan", Proceedings, Faculty of Law, Novi Sad 1, 2006, 66. 
Collectio Novelarum = Jus Graeco-Romanum III, ed. C. E. Zachariae v. Lingenthal, Lipsiae 1873

Dj. Krstic, Dusan's Code: Bistrica transcript, Belgrade 1994.

D. Obolensky, Byzantine Commonwealth: Eastern Europe, 500-1453 (America Council of Learned Societies), May 1, 2009

E. H. Freshfield, A manual of Eastern Roman law THE PROCHEIROS NOMOS, Cambridge MCMXXVIII

G. Ostrogorski, History of Byzantium, Education, Belgrade 1969

C. Mitrovic, Ecclesiastical Law, Belgrade 1929.

J. Coder, Byzantine World, Utopia, Belgrade 2011.

J. Murray, Codex Theodosianus, A Dictionary of Greek and Roman Antiquities, London 1875.

M. Tomic, The Death Penalty in Criminal Law, Belgrade 1985

N. Radojcic, Code of Emperor Stefan Dusan 1349 and 1354, Belgrade 1960.

N. Radojcic, Dusan's Code and Byzantine Law, Proceedings in Honor of the Sixth Centenary of Emperor Dusan's Code, Belgrade 1951.

N. Selakovic, Dusan's Code and Legal Transplants, Belgrade 2007, Prochiron (O

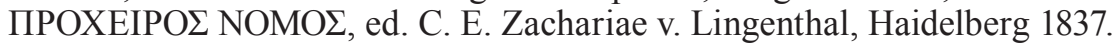

C. Avramovic, General Legal History-Old and Middle Ages, Belgrade 2000.

C. Savic, History of the Death Penalty in Serbs, Proceedings, Faculty of Law University of East Sarajevo 2011

St. Novakovic, Code of the Emperor Stefan Dusan 1349 and 1354, Belgrade 1960.

St. Novakovic, Legal Monuments of the Serbian States of the Middle Ages, Belgrade 1912.

St. Novakovic, Syntagma of Matthias Vlastar, Belgrade 1907.

C. Dill, History of Byzantium, Edition, Belgrade 2010,

T. Taranovski, History of Serbian Law in the Nemanjic State, Belgrade 1931.

L J. Krkljus, Selected Sources in the Legal History of the Serbian People, Novi Sad 2003. 


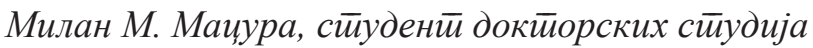
Универзитеиеи у Беог̄раду

Правни факулиетеи у Беог̄раду

milan.macura992@gmail.com

\section{Византијско право као расадник правних транспланта са посебним освртом на Душанов законик}

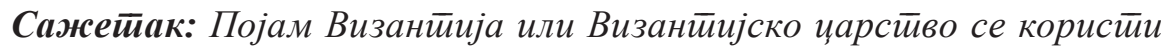
државну ииворевину која је йосйојала у иериоду од IV йа све до XV века, йачније до 1453. гоодине и йада Царигррада услед османских освајања. Без обзира на йо какве су истиоријске дискусије и мищљена која се иначе разилазе у вези са наситанком Визанитије, у овом научном раду као зачетиак Визан-

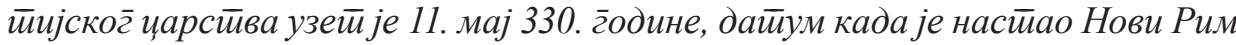

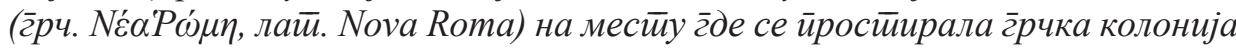

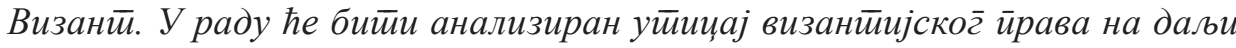

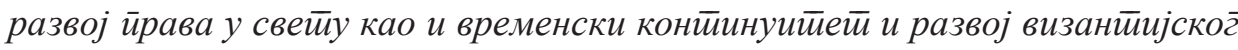
иррава које се ослања на римско ирраво. Осим йог̄а, кроз уйоређивање чланова визанйијских законика и касније Дущановог̄ законика, Закона Пройе Майеје Ненадовића и Карађорђевог̄ законика, биће аналикирана тееорија йравних

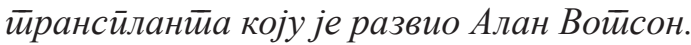

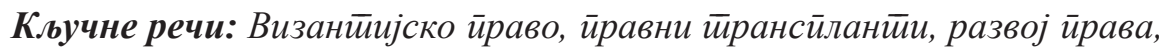
Визаниичјско иарсивво, римско йраво.

Датум пријема рада: 24.05.2018. 